\title{
Examining Levels of Depression, Anxiety, and Stress Experienced by Nurses during the COVID-19 Pandemic
}

\section{Elif ISIK', Yalcin KANBAY ${ }^{1}$, Hatice ISKENDER ${ }^{1^{*}}$ and Ozgur ASLAN ${ }^{2}$}

${ }^{1}$ Faculty of Health Sciences, Artvin Coruh University, Artvin, Turkey

${ }^{2}$ Vocational School of Health Services, Kafkas University, Kars, Turkey

*Corresponding author: Dr. Hatice Iskender, Department of Nutrition and Dietetics, Faculty of Health Sciences, Artvin Coruh University, 08000 Artvin, Turkey, Tel: +90-466-215-1063

\begin{abstract}
Background: The novel coronavirus (COVID-19) outbreak began in Wuhan, China in December 2019 and has spread rapidly across the world. Since the healthcare professionals, who have worked devotedly for fighting against the COVID-19, they have been most affected by the virus.
\end{abstract}

Aim: The aim of this study was to examine the levels of depression, anxiety, and stress experienced by nurses during the COVID-19 pandemic and the influencing factors.

Methods: The sample consisted of 482 nurses working in various institutions and the data were examined by the descriptive statistics and the structural equation modeling.

Result: The results of the study indicated that depression and stress scores were higher in female nurses than male counterparts, in those who unwillingly preferred their jobs than those who willingly preferred, and in those who were dissatisfied with their jobs than those who were satisfied.

Conclusions: In the present study, it was concluded that the nurses experienced psychological problems during the COVID-19 pandemic.

\section{Keywords}

Novel coronavirus (COVID-19), Nurse, Depression, Stress, Anxiety

\section{Introduction}

The novel coronavirus (COVID-19) outbreak began in Wuhan, China in December 2019 [1] and has spread rapidly to the rest of the world [2]. Hereupon, the World Health Organization (WHO) declared COVID-19 a pandemic on 11 March 2020 [3]. WHO has reported that a great number of people have been infected with the coronavirus, the disease has increasingly caused many deaths [4]. The first case in Turkey was reported on 11 March 2020 and afterwards, the measures have been incrementally taken throughout the country to prevent and decrease the spreading of the virus [5].

Adverse effects of the pandemic have been observed in numerous areas such as health, economy, sociology, psychology, and education. The magnitude of this adverse effect is growing day by day and it is worrisome [6]. Although symptoms of COVID-19 such as fever, cough, and respiratory distress are similar to epidemic SARS disease, infected people may develop no symptom or some symptoms such as fever, cough, shortness of breath, pneumonia, respiratory distress, diarrhea, vomiting, and abdominal pain or they may die $[7,8]$. Epidemics cause severe effects on mental health in society as well as physical damages [9]. Some of previous epidemiological studies reported that the survivors of SARS epidemic suffered from depression, anxiety, negative psychological effect, panic attack, psychomotor agitation, psychotic symptoms, delirium, and even suicidality $[10,11]$.

The risk of infection is higher in physicians, nurses and other healthcare professionals who treat and provide care for the COVID-19 patients than the people [12]. The healthcare professionals perform the most important duties in the fight against both the COVID-19 disease and all epidemics and therefore, their risk of being infected with the pathogen causing the pandemic is higher. Also, the infected healthcare professionals

Citation: ISIK E, KANBAY Y, ISKENDER H, ASLAN O (2021) Examining Levels of Depression, Anxiety, and Stress Experienced by Nurses during the COVID-19 Pandemic. Int Arch Nurs Health Care 7:167. doi. org/10.23937/2469-5823/1510167

Accepted: October 13, 2021: Published: October 15, 2021

Copyright: (C) 2021 ISIK E, et al. This is an open-access article distributed under the terms of the Creative Commons Attribution License, which permits unrestricted use, distribution, and reproduction in any medium, provided the original author and source are credited. 
can cause the disease to spread, thus magnifying the problem. The World Health Organization states that the risks and dangers encountered by the healthcare professionals include long working hours, psychological stress, extreme fatigue, professional burnout, and physical and psychological violence besides exposure to pathogen [13].

Nurses, one of the most important healthcare professional groups, have crucial duties in health protection and promotion of individuals, families and community and treatment of diseases [14]. Also, nurses are the healthcare professionals who spend far more time with patients and they are the first to find solutions for all kinds of problems experienced by patients and their families. Working under intense stress may affect healthcare professionals psychologically, in turn resulting in impairment in their life quality [14,15]. Nurses who have worked for long hours during the pandemic period suffer from fatigue and have fears of being infected from the patients and infecting their children, relatives and close friends [16], thus leading to common mental health problems such as anxiety and depression [17]. The aim of this study was to examine the levels of depression, anxiety, and stress experienced by nurses during the COVID-19 pandemic and the influencing factors.

\section{Methods}

\section{Study design}

This study was conducted with cross-sectional design to determine the factors related to depression, anxiety, and stress experienced by nurses.

\section{Setting}

The study was conducted with the nurses who were working in different cities in Turkey, were contacted through the online communication networks such as e-mail and Whatsapp, agreed to participate in the study, and completed fully the data collection forms.

\section{Population and sample}

Sample selection was not used in the study and 482 nurses who were contacted online and agreed to participate in the study were included in the study.

\section{Data collection}

The data were collected online through various applications to eliminate risk of COVID-19 infection. "Socio-demographic Characteristics Form" and "Depression, Anxiety, Stress Scale (DASS - 42)" were used as the data collection tools. The first COVID-19 case in Turkey was reported on 11 March 2020. Hereupon, necessary measures have been taken throughout the country and the extent of the measures has been expanded with the increasing number of cases. During this period, the healthcare professionals have performed their jobs devotedly but it was observed that depression, anxiety and stress levels of the healthcare professionals have increased due to the both the dimensions of the pandemic and its negative effects on their psycho-social lives. For this reason, this study was planned to determine the levels of these variables in nurses and the data were collected in May 2020.

\section{Socio-demographic characteristics form}

This form was prepared by the researcher upon the literature reviews to assess the socio-characteristics of the participants.

\section{Depression anxiety stress scale (DASS-42)}

The scale was developed by Lovibond and Lovibond in 1995 [18]. Bilgel and Bayram [19] adapted the scale into Turkish and conducted its reliability and validity study. The scale has 42 items which are rated via a 4-point likert scale ( 0 = never, 1 = sometimes, 2 = quite often, 3 = always) and three subscales (depression, anxiety and stress). In the original version of the scale, the normal interval is 0-9 for depression subscale, 0-7 for anxiety subscale, and 0-14 for stress subscale. Its Turkish version, the cutoff points were calculated to be 10 for depression subscale and 7 for anxiety subscale. Psychometric properties of Turkish version of the Depression Anxiety Stress Scale (DASS-42) were also determined. In the reliability study of its Turkish version, Cronbach's alpha internal consistency coefficients were calculated to be 0.9 for depression subscale, 0.86 for anxiety subscale, and 0.88 for stress, subscale [19]. In this study, its "Anxiety" subscale was excluded from Structural Equation Modeling (SEM) as it did not show concordance with the model.

\section{Data analysis}

The data analysis was performed in two stages. SPSS 23 software was used for the descriptive statistics. SEM was also used to determine the factors which were effective on depression, anxiety, and stress. AMOS 23 software was used for SEM.

\section{Ethical considerations}

Ethics committee approval was obtained from University (The session dated 15.04.2020 and numbered 2020/5) and whoever filled the survey considered consented of the healthcare professionals was obtained. Participation in the study was based on voluntariness.

\section{Results}

It was found that $82.8 \%$ of the participants were female and majority of them were married (71.2\%). Most of the participants had a bachelor's degree. $82.8 \%$ preferred this profession willingly but $25.2 \%$ were not satisfied with their profession and $27.4 \%$ were indecisive. While $63.1 \%$ were working in shifts, $36.9 \%$ were working during day shift. The age average of the 
Table 1: Demographics of the participants $(n=482)$.

\begin{tabular}{|c|c|c|c|c|c|}
\hline Parameter & $\mathbf{n}$ & $\%$ & Parameter & $\mathbf{n}$ & $\%$ \\
\hline Gender & & & Education level & & \\
\hline Female & 399 & 82.8 & High school & 46 & 9.5 \\
\hline Male & 83 & 17.2 & Associate degree & 86 & 17.8 \\
\hline Marital status & & & Bachelor's degree & 297 & 61.6 \\
\hline Single & 139 & 28.8 & Graduate & 53 & 11.0 \\
\hline Married & 343 & 71.2 & Profession satisfaction & & \\
\hline Preferring profession & & & Dissatisfied & 121 & 25.1 \\
\hline Unwillingly & 83 & 17.2 & Indecisive & 132 & 27.4 \\
\hline Willingly & 399 & 82.8 & Satisfied & 229 & 47.5 \\
\hline \multicolumn{6}{|l|}{ Type of work } \\
\hline Daytime & 178 & 36.9 & & & \\
\hline \multirow[t]{2}{*}{ Shift } & 304 & 63.1 & & & \\
\hline & Mean & Standard deviation & & & \\
\hline Age & 35.5 & 7.7 & & & \\
\hline Number of children & 1.2 & 1.0 & & & \\
\hline Tenure & 13.7 & 8.3 & & & \\
\hline
\end{tabular}

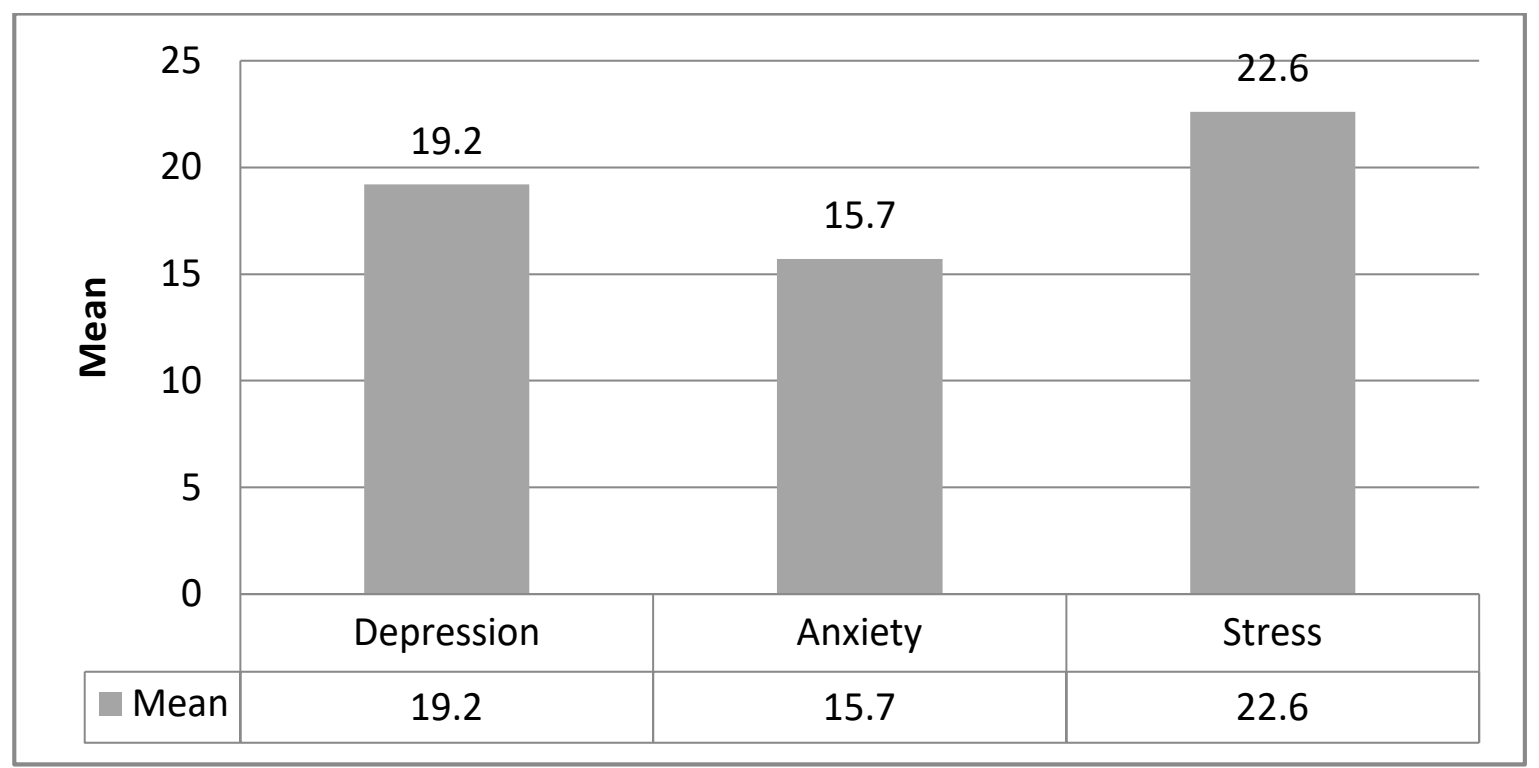

Graphic 1: The mean values of DASS-42 subscales.

participants was $35.5 \pm 7.7$, their number of children was $1.2 \pm 1.0$, and their tenure was $13.7 \pm 8.3$ years (Table 1).

When examining the mean values of the subscales of DASS-42, it was determined that mean score of "Depression subscale" was $19.2 \pm 11.3$, mean score of "Anxiety subscale" was $15.7 \pm 10.1$, and mean score of "Stress subscale" was $22.6 \pm 10.5$ (Graphic 1).

The 14-item structure of DASS-42 Depression subscale was tested with the first level single factor CFA. As the data were normally distributed, the maximum likelihood calculation method was used. It was observed that the factor loads of the items in this subscale varied between 0.64 and 0.84 . The results revealed that as a result of the fit indices, the measurement model related to DASS-42 Depression subscale was confirmed. The fit indices were determined to be $\chi^{2}=247.34, \chi^{2} / \mathrm{df}=$ 3.342, $\mathrm{NFI}=0.95, \mathrm{TLI}=0.96, \mathrm{CFI}=0.96, \mathrm{GFI}=0.93, \mathrm{AGFI}$ $=0.90, \mathrm{RMSEA}=0.07$, and $\mathrm{RMR}=0.04$. The regression coefficient of the model was determined to be 0.41 and accounted for $41 \%$ of the variance of depression. The goodness of fit values obtained as a result of the first level CFA were acceptable and compatible with the proposed model. These results demonstrated that the data were compatible with the theoretical structure of DASS-42 Depression subscale.

The 14-item structure of DASS-42 Stress subscale was tested with the first level single factor CFA. As the data were normally distributed, the maximum likelihood calculation method was used. The factor loads of the items in this subscale varied between 0.55 
and 0.82 . The results indicated that as a result of the fit indices, the measurement model related to DASS-42 Stress subscale was confirmed. The fit indices were $\chi^{2}=$ $272.96, \chi^{2} / \mathrm{df}=43.689, \mathrm{NFI}=0.94, \mathrm{TLI}=0.94, \mathrm{CFI}=0.95$, $\mathrm{GFI}=0.93, \mathrm{AGFI}=0.90, \mathrm{RMSEA}=0.07$, and $\mathrm{RMR}=0.04$. The model accounted for $49 \%$ of the variance of stress. It was observed that the goodness of fit values obtained as a result of the first level CFA were acceptable and compatible with the proposed model. These results demonstrated that the data were compatible with the theoretical structure of DASS-42 Stress subscale (Figure 1).

According to Table 2, Cronbach's a reliability coefficient was calculated to be 0.95 and 0.94 for depression and stress subscales, respectively. These values expressed high level of reliability.

Table 2: Reliability findings related to DASS-42 depression and stress subscales.

\begin{tabular}{|l|l|l|}
\hline Scale & Number of items & Cronbach's $\mathbf{\alpha}$ \\
\hline Depression subscale & 14 & 0.95 \\
\hline Stress subscale & 14 & 0.94 \\
\hline
\end{tabular}

*The Anxiety subscale was excluded from SEM as it was not compatible with the model.
A structural model was established to estimate the factors causing depression and its goodness of fit values were examined. The variables such as age, marital status (married/single), number of children, educational level (high school $\rightarrow$ doctorate), status of preferring profession (willingly/unwillingly), tenure in the profession, type of work (shift/only daytime) and the status of being satisfied with the unit (dissatisfied/ indecisive/satisfied) were added in the model. Based on the goodness of fit values of the model $\left(\chi^{2}=849.46, \chi^{2}\right)$ $d f=3.79, \mathrm{NFI}=0.87, \mathrm{TLI}=0.89, \mathrm{CFI}=0.90, \mathrm{GFI}=0.87$, $A G F I=0.84, R M S E A=0.08, R M R=0.49$ ), they were not at the desired level. For this reason, the standardized regression coefficients of the model were examined to obtain a better model (Figure 2).

When the standardized regression weights of the variables included in the estimation model and significance of their contribution to the model were examined according to Table 3 , it was determined that "age", "marital status", "number of children", "educational status", "tenure", "choosing profession willingly" and "type of work" parameters did not show a significant correlation with the model $(p>0.05)$. Also, all of the goodness of fit values of the structural model

Table 3: Regression weights of the model defining the factors affecting depression.

\begin{tabular}{|l|l|l|l|l|}
\hline Parameter & & $\begin{array}{l}\text { Implicit } \\
\text { structure }\end{array}$ & $\begin{array}{l}\text { Standardized } \\
\text { Regression } \\
\text { Weight }\end{array}$ & p \\
\hline Age & & Depression & -0.010 & 0.829 \\
\hline Marital status & $<--$ & Depression & -0.041 & 0.389 \\
\hline Number of children & $<--$ & Depression & -0.048 & 0.310 \\
\hline Education level & $<---$ & Depression & -0.052 & 0.270 \\
\hline Preferring profession & $<---$ & Depression & -0.134 & 0.004 \\
\hline Tenure & $<---$ & Depression & 0.024 & 0.616 \\
\hline Type of work & $<---$ & Depression & 0.056 & 0.236 \\
\hline Satisfaction with Profession & $<---$ & -0.316 & 0.000 \\
\hline
\end{tabular}
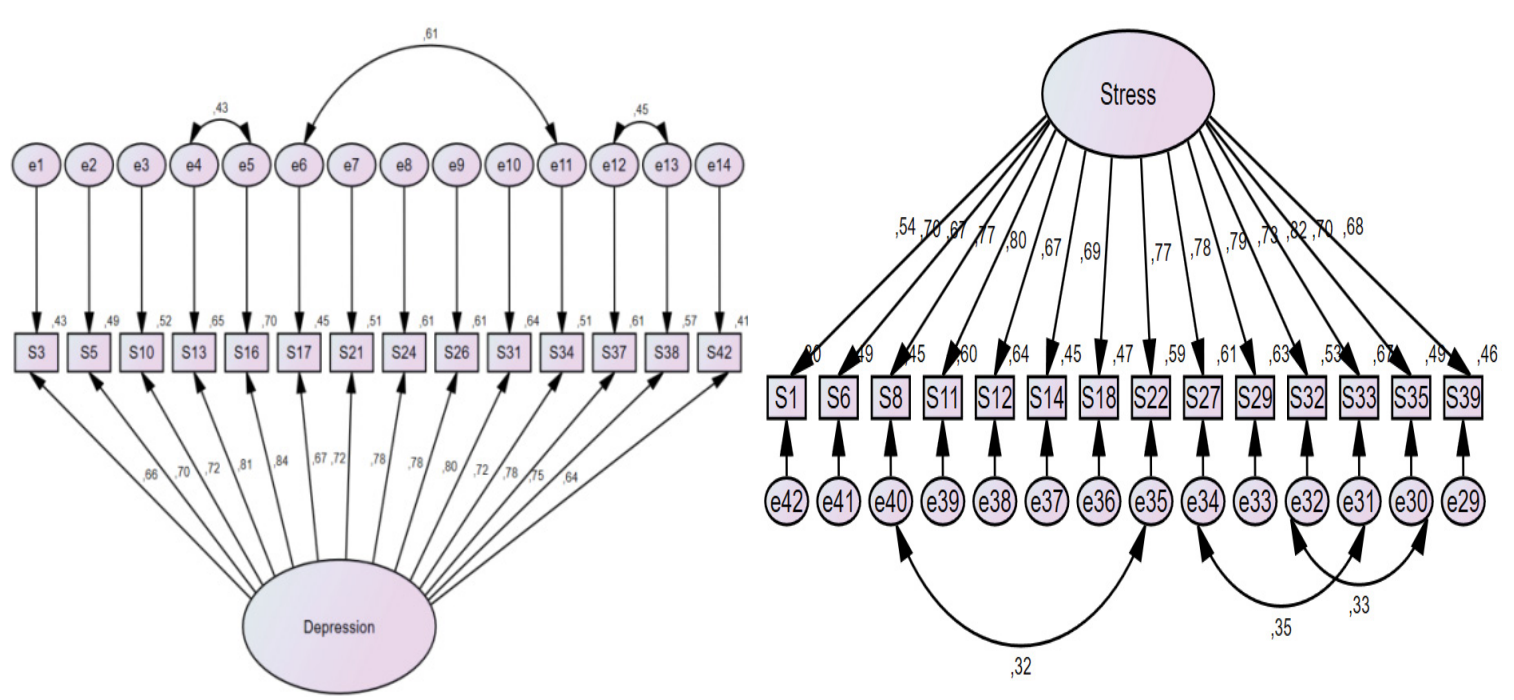

Figure 1: Measurement model path diagrams of DASS-42 scale depression and stress subscales. 


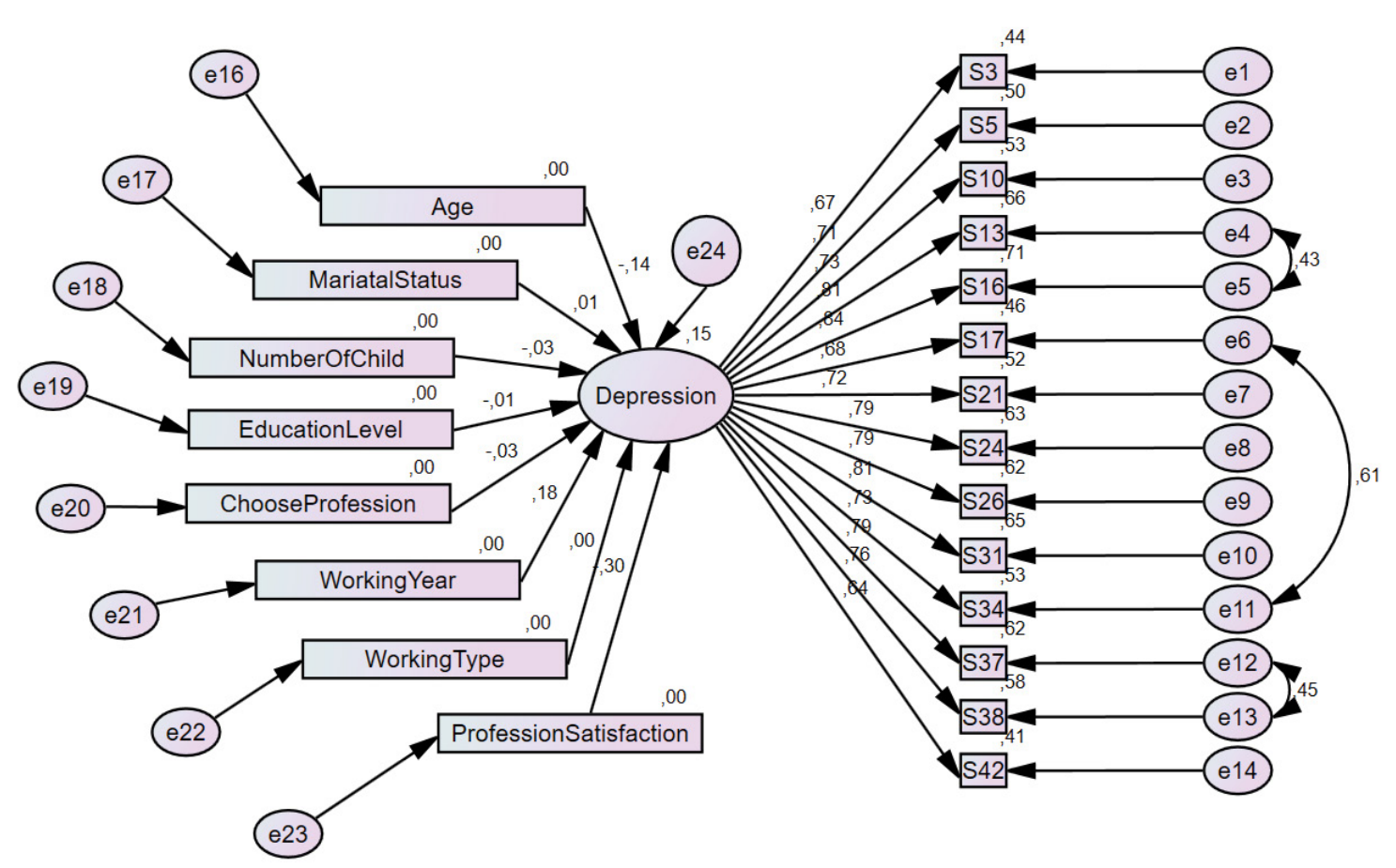

Figure 2: Initial structural model estimating the factors affecting depression.

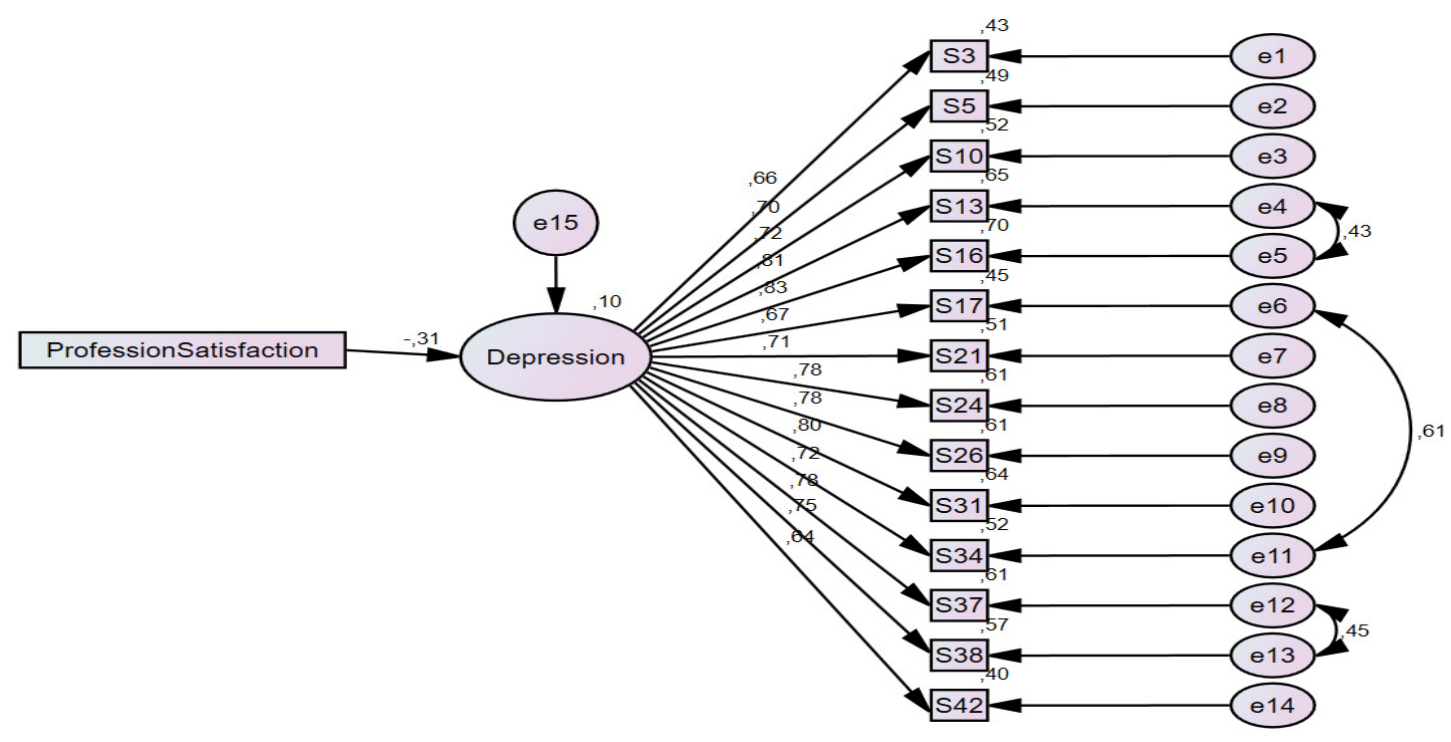

Figure 3: Revised model estimating the factors affecting depression.

were not at an acceptable level. For these reasons, the parameters showing a significant correlation with the model were excluded from the analysis and a new structural model was established in order to have a model with higher goodness of fit values or increase the compliance of the model to the dataset.

When the revised model estimating the factors affecting depression and its goodness of fit values were examined, it was determined that the goodness of fit values of the model was at an acceptable level $\left(\chi^{2}=\right.$ 382.64, $\chi^{2} / d f=3.299, N F I=0.92, T L I=0.94, C F I=0.95$, $G F I=0.91, A G F I=0.88, R M S E A=0.07, R M R=0.04)$ and the model was put into final form. Gender $(\mathrm{t}=-3.839 ; \mathrm{p}$
$<0.001)$, status of preferring the profession willingly $(t=$ -2.963; $p<0.05)$, and satisfaction $(t=-6.650 ; p<0.001)$ parameters had a significant effect on depression. Based on the standardized regression coefficients in the model it was determined that especially the effect of the "satisfaction" variable (32\%), among these independent variables found to be significant, was more compared to the other variables. The depression score of those who were dissatisfied with their profession was higher by $32 \%$ (Figure 3 ).

A structural model was established to estimate the factors affecting stress and the goodness of fit values of this model were examined. The variables such as age, 
Table 4: Regression weights of the model defining the factors affecting stress.

\begin{tabular}{|l|l|l|l|l|}
\hline Parameter & & $\begin{array}{l}\text { Implicit } \\
\text { structure }\end{array}$ & $\begin{array}{l}\text { Standardized } \\
\text { Regression } \\
\text { weight }\end{array}$ & p \\
\hline Age & & Stress & -0.010 & 0.826 \\
\hline Marital status & $<---$ & Stress & -0.042 & 0.371 \\
\hline Number of children & $<---$ & Stress & -0.049 & 0.295 \\
\hline Education level & $<---$ & Stress & -0.051 & 0.275 \\
\hline Preferring profession & $<---$ & Stress & -0.141 & 0.003 \\
\hline Tenure & $<---$ & Stress & 0.022 & 0.645 \\
\hline Type of work & $<---$ & Stress & 0.057 & 0.228 \\
\hline Satisfaction with Profession & $<---$ & Stress & -0.319 & 0.000 \\
\hline
\end{tabular}

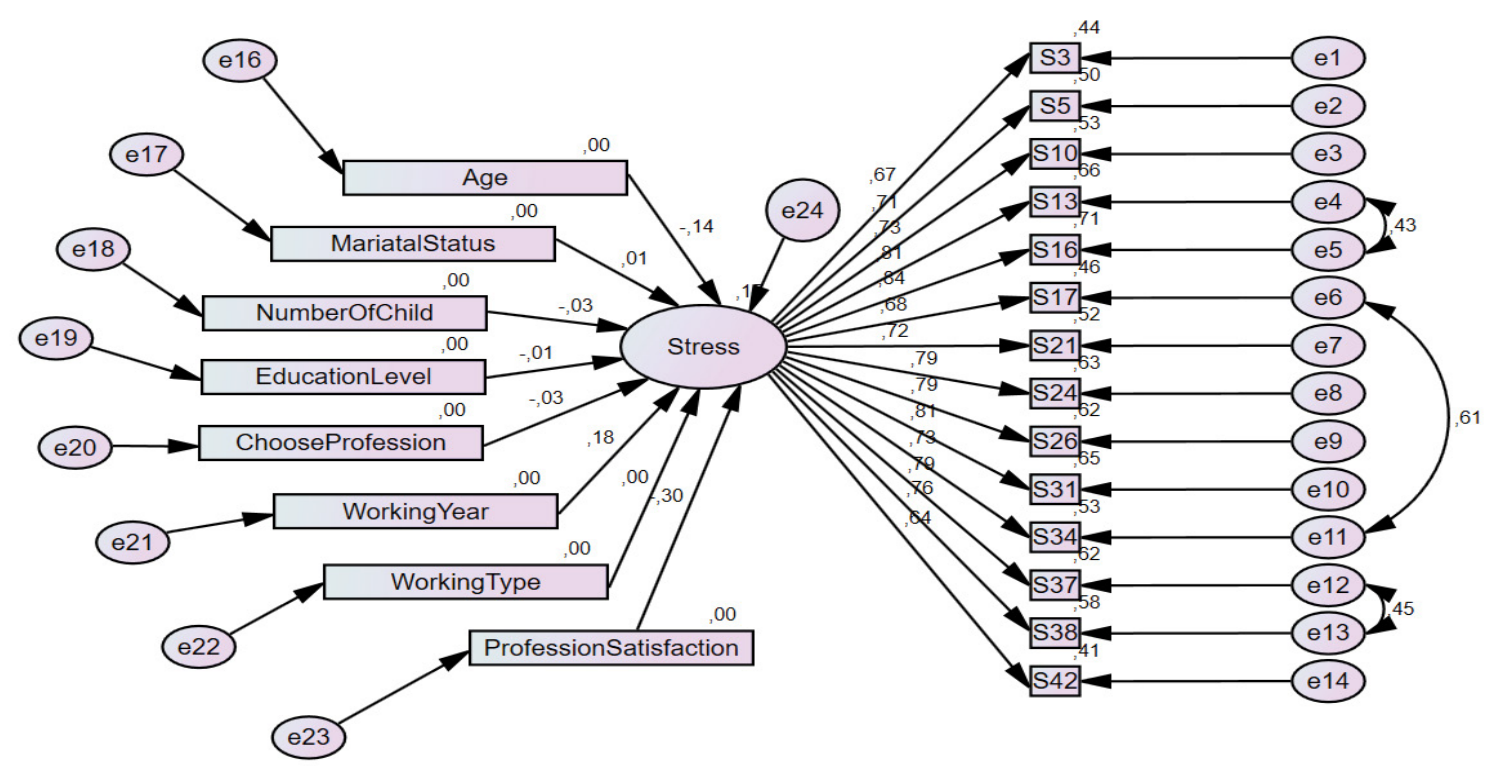

Figure 4: Initial structural model estimating the factors affecting stress.

marital status (married/single), number of children, educational level (high school $\rightarrow$ doctorate), the status of preferring profession (willingly/unwillingly), tenure in the profession, type of work (shift/only daytime) and being satisfied with the unit (dissatisfied/indecisive/ satisfied) were added in the model. When the goodness of fit values of the model $\left(\chi^{2}=2002.569, \chi^{2} / d f=8.822\right.$, $\mathrm{NFI}=0.70, \mathrm{TLI}=0.69, \mathrm{CFI}=0.72, \mathrm{GFI}=0.75, \mathrm{AGFI}=$ $0.70, R M S E A=0.13, R M R=3.60$ ) were examined, it was determined that they were not at the desired level. For this reason, the standardized regression coefficients of the model were examined to obtain a better model (Figure 4).

When the standardized regression weights included in the estimation model and significance of their contribution to the model were examined according to Table 4, it was determined that "age", "marital status", "number of children", "educational status", "tenure", "preferring the profession willingly" and "type of work" parameters did not show a significant correlation with the model $(p>0.05)$. The parameters showing a significant correlation with the model were excluded from the analysis and a new structural model was established in order to have a model with higher goodness of fit values or increase the compliance of the model to the data set.

When the revised model estimating the factors affecting stress and its goodness of fit values were examined, it was determined that the goodness of fit values of the model was at an acceptable level $\left(\chi^{2}=\right.$ 337.38, $\chi^{2} / d f=2.934, N F I=0.93, T L I=0.95, C F I=0.96$, $G F I=0.92, A G F I=0.90, R M S E A=0.06, R M R=0.04)$ and the model was put into final form. It was determined that gender $(\mathrm{t}=-3.826 ; \mathrm{p}<0.001)$, the status of preferring the profession willingly $(t=-2.827$; $p<0.05)$, and satisfaction ( $t=-6.595 ; p<0.001$ ) parameters had a significant effect on stress. Based on the standardized regression coefficients in the model it was determined that especially the effect of the "satisfaction" variable (31\%), among these independent variables found to be significant, was higher compared to the other variables. The stress score of those who were dissatisfied with their profession was higher by $31 \%$ (Figure 5). 


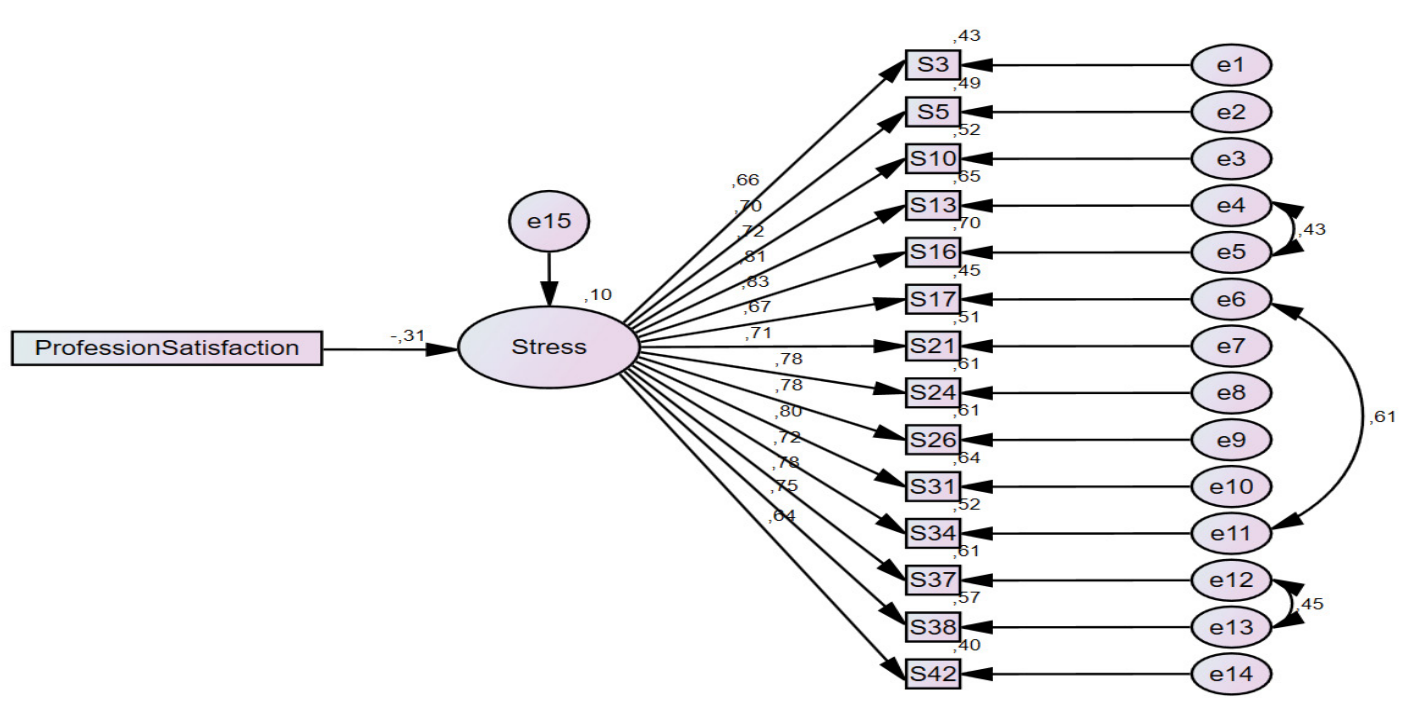

Figure 5: Revised model estimating the factors affecting stress.

\section{Discussion}

This study was conducted to reveal the levels of depression, anxiety, and stress experienced by nurses working devotedly during the COVID-19 pandemic as well as the influencing factors. The first case in Turkey was announced by the Ministry of Health on 11 March 2020 and then the number of cases has increased day by day. This has affected negatively the mental state of both people and healthcare professionals [5]. The anxiety and stress level of the society has been higher compared to the other times due to infection risk of the disease, the interrupted work life, lack of treatment or preventive vaccine for the disease, staying at their homes and working at home [20]. During this pandemic, the psychological problems observed throughout the society such as stress, anxiety, and depression have started to be seen more often in the healthcare professionals [21]. Also, Graphic 1 shows the depression, anxiety, and stress findings seen in nurses based on DASS-42 subscales in this study. Similarly, there are studies revealing the depression, anxiety and stress levels in healthcare professionals and nurses $[22,23]$.

Nurses have had a great role in the preventive and therapeutic aspects during the COVID-19 pandemic and they have faced many risks. The most important one of these risks is the infection risk. Also, they have experienced psychological problems due to the risk of infection and while providing care to these patients [24]. In a similar study conducted with healthcare professionals during the COVID-19 pandemic, they suffered from moderate or severe depression [21,25]. Healthcare professionals experience anxiety, panic, depression and stress due to the fact that they have been infected by the disease, they are at risk of infecting their families, they have been put in quarantine in hospitals and there has been an uncertainty about the disease $[22,26]$. The results of the present study were compatible with those obtained in the international studies.

In the depression and stress modeling performed in the study, depression and stress factors were higher and significant in females than males, in those who unwillingly preferred the profession than those who willingly preferred the profession, and in those who were dissatisfied with the profession than those who were satisfied with the profession.

The depression and stress scores of the female nurses are also higher than the scores of male nurses in times other than this pandemic period [27]. This has remained the same during the pandemic. However, women think that they will have more risk to infect due to their roles in the family and they have kept away from their families within this period. This was thought to be effective in the depression and stress scores. In another study conducted during the pandemic, it was determined that women experienced more psychological problems compared to men and their requests for psychological treatment were estimated to increase [28]. Studies conducted during the pandemic have supported this view $[21,29]$. In a study conducted during the pandemic, it was determined that women experienced a higher level of depression [30] and psychosocial problems [20] compared to men. In another study, it was stated that living or working with the confirmed COVID-19 patients was a condition increasing the mental effects [31]. It was also predicted that COVID-19 would cause depression and mental effects not only on healthcare professionals but also the whole society and this will last for long years as a result of the pandemics and disasters in the past [30-32]. Likewise, in a study conducted with healthcare professionals in 2003 during the SARS epidemic, it was observed that psychological problems such as chronic stress and high level of depression were experienced [33]. 
Professional satisfaction is an essential element especially in nursing under any circumstance(s) whatsoever. Nurses have lower depression and stress scores as long as they have professional satisfaction regardless of their working conditions, salaries, and units. This study supported this view. Providing social support for healthcare professionals by showing respect and tolerance towards them, making them feel professional achievement, and providing courage would increase their satisfaction with the profession and help lower their stress level [34]. Nurses are the healthcare professionals who are the first to face with patients and have the first contact with them in all pandemics and they have worked with great devotion. The fact that nurses have withstood harsh conditions experienced during the pandemic may be explained with the professional satisfaction resulting from the value they attribute to human life [24].

The greatest risk of healthcare professionals during the pandemic is to face with the infection [35]. The fact that nurses have difficult working conditions during the pandemic and they have done their best despite all the deficiencies appears as an indicator of how good they are in human relations and they perform their jobs willingly [24]. Preferring the profession willingly is very important for nurses who work in a profession aiming at helping people or serve them and mostly in the health institutions which are included in the service sector [36]. In another study, it was reported that nurses fought against both pandemic and the stress they have experienced during the pandemic $[22,24]$.

As seen in this study, it was also observed that the depression and stress scores of the nurses who preferred their profession willingly were lower despite pandemic conditions. The fact that nurses did not prefer nursing profession willingly and they regretted about their profession increased their stress and anxiety levels and similarly, infection and unwillingness caused stress and depression during previous H1N1 pandemic [22]. Nursing is considered as a stressful profession due to the reasons such as working conditions, work load, role conflict and this is effective in preferring this profession. Few stressors are seen in those who prefer their profession willingly $[37,38]$.

\section{Conclusion}

The results of the study indicated that variables of gender, status of preferring the profession willingly and status of being satisfied with the profession were the factors affecting the depression and stress levels of the nurses. Depression and stress scores were higher in female nurses than male counterparts, in those who unwillingly preferred the profession than those who willingly preferred the profession, and in those who were dissatisfied with the profession than those who were satisfied with the profession. However, the personal and professional characteristics such as age, marital status, number of children, educational status, tenure, and type of work were not associated with the depression and stress levels. Nurses constitute the most important professional group of healthcare providers. Nurses are at the forefront of healthcare delivery, both in the fight against epidemics and while providing care to patients suffering from other diseases. Pandemic infections affect healthcare workers and society negatively with regard to their psychology. Nurses in the risk group are strengthened to be protected from depression and stress and the administrative and political decision makers take this variable into consideration in the decisions they will make about the nursing services. Due to the effect of job satisfaction on depression and stress, it is also recommended to improve working conditions, increase the employee satisfaction, to determine the factors increasing the employee satisfaction, and perform relevant interventions.

\section{Limitations}

This study includes nurses who can be reached by email across the country. It cannot be owned by the whole world. However, it has been shown in the study that there are similar problems all over the world.

\section{Acknowledgements}

None.

\section{Conflict of Interest}

The authors declared no conflicts of interest.

\section{References}

1. Lu H, Stratton CW, Tang YW (2020) Outbreak of pneumonia of unknown etiology in Wuhan, China: The mystery and the miracle. J Med Virol 92: 401-402.

2. Wang C, Horby PW, Hayden FG, Gao GF (2020) A novel coronavirus outbreak of global health concern. Lancet 395 : 470-473.

3. Huang Y, Zhao N (2020) Generalized anxiety disorder, depressive symptoms and sleep quality during COVID-19 outbreak in China: A web-based cross-sectional survey. Psychiatry Res 288: 112954.

4. World Health Organization (2020) Novel coronavirus (2019$\mathrm{nCoV})$.

5. (2020) COVID-19 Pandemi değerlendirme raporu. Türkiye Bilimler Akademisi, Ankara.

6. Chen X, Yu B (2020) First two months of the 2019 Coronavirus Disease (COVID-19) epidemic in China: Realtime surveillance and evaluation with a second derivative model. Glob Health Research Policy 5: 7.

7. Júnior Borges do Nascimento I, Cacic N, Abdulazeem HM, Caspar von Groote T, Jayarajah U, et al. (2020) Novel coronavirus infection (COVID-19) in Humans: A scoping review and meta-analysis. J Clin Med 9: 941.

8. Emami A, Javanmardi F, Pirbonyeh N, Akbari A (2020) Prevalence of underlying diseases in hospitalized patients with COVID-19: A Systematic Review and Meta Analysis. Arch Acad Emerg Med 8: e35. 
9. Xinhuanet (2020) China confirms human-to-human transmission of $2019 \mathrm{nCoV}$, infections among medical staff. The Latest.

10. Maunder R, Hunter J, Vincent L, Bennett J, Peladeau N, et al. (2003) The immediate psychological and occupational impact of the 2003 SARS outbreak in a teaching hospital. CMAJ 168: 1245-1251.

11. Lee AM, Wong JGWS, McAlonan GM, Cheung V, Cheung C, Sham PC, et al. (2007) Stress and psychological distress among SARS survivors 1 year after the outbreak. Can J Psychiatry 52: 233-240.

12. Al-Rabiaah A, Temsah MH, Al-Eyadhy AA, Hasan GM, AlZamil F, et al. (2020) Middle East respiratory syndromecorona virus (MERS-CoV) associated stress among medical students at a university teaching hospital in Saudi Arabia. J Infect Public Health 13: 687-691.

13. https://www.ttb.org.tr/userfiles/files/TTB-22-Mart-BakanYazi.pdf

14. Coster S, Watkins M, Norman IJ (2018) What is the impact of professional nursing on patients' outcomes globally? An overview of research evidence. Int J Nurs Stud 78: 76-83.

15. Sarafis $P$, Rousaki E, Tsounis A, Malliarou M, Lahana L, et al. (2016) The impact of occupational stress on nurses' caring behaviors and their health related quality of life. BMC Nurs 15: 56.

16. Xiang YT, Yang Y, Li W, Zhang L, Zhang Q, et al. (2020) Timely mental health care for the 2019 novel coronavirus outbreak is urgently needed. Lancet Psychiatry 7: 228-229.

17. Dar KA, Iqbal N, Mushtaq A (2017) Intolerance of uncertainty, depression, and anxiety: Examining the indirect and moderating effects of worry. Asian J Psychiatr 29: $129-133$.

18. Lovibond PF, Lovibond SH (1995) The structure of negative emotional states: Comparison of the Depression Anxiety Stress Scales (DASS) with the beck depression and anxiety inventories. Behav Res Ther 33: 335-343.

19. Bilgel N, Bayram N (2010) Turkish version of the Depression Anxiety Stress Scale (DASS-42): Psychometric properties. Nöropsikiyatri Arsivi 47: 118-126.

20. Ekiz T, Iliman E, Donmez E (2020) Bireylerin sağlik anksiyetesi düzeyleri ile COVID-19 salgini kontrol algisinin karşilaştirilmasi. Uluslararasi Sağlik Yönetimi ve Stratejileri Araştirma Dergisi 6: 139-154.

21. Chew NWS, Lee GKH, Tan BYQ, Jing M, Goh Y, et al. (2020) A multinational, multicentre study on the psychological outcomes and associated physical symptoms amongst healthcare workers during COVID-19 outbreak. Brain Behav Immun 88: 559-565.

22. Cui S, Jiang Y, Shi Q, Zhang L, Kong D, et al. (2020) Impact of COVID-19 on psychology of nurses working in the emergency and fever outpatient: A cross-sectional survey.

23. Mo Y, Deng L, Zhang L, Lang Q, Liao C, et al. (2020) Work stress among Chinese nurses to support Wuhan in fighting against COVID-19 epidemic. J Nurs Manag 28: 1002-1009.
24. Buheji M, Buhaid N (2020) Nursing human factor during COVID-19 pandemic. International Journal of Nursing Science 10: 12-24.

25. Pappa S, Ntella V, Giannakas T, Giannakoulis VG, Papoutsi E, et al. (2020) Prevalence of depression, anxiety, and insomnia among healthcare workers during the COVID-19 pandemic: A systematic review and meta-analysis. Brain Behav Immun 88: 901-907.

26. Chen Q, Liang M, Li Y, Guo J, Fei D, et al. (2020) Mental health care for medical staff in China during the COVID-19 outbreak. Lancet Psychiatry 7: e15-e16.

27. Kizilirmak M, Demir S (2016) Hastanede çalişan hemşirelerde depresyon ve yaşam kalitesinin incelenmesi. TAF Preventive Medicine Bulletin 15: 132-140.

28. Sønderskov KM, Dinesen PT, Santini ZI, Østergaard SD (2020) The depressive state of Denmark during the COVID-19 pandemic. Acta Neuropsychiatr 32: 226-228.

29. Maben J, Bridges J (2020) COVID-19: Supporting nurses' psychological and mental health. J Clin Nurs 29: 27422750.

30. Ahmed MZ, Ahmed O, Aiboa Z, Hanbin S, Siyu L, et al. (2020) Epidemic of COVID-19 in China and associated psychological problems. Asian J Psychiatr 51: 102092.

31. Kaya B (2020) Pandeminin ruh sağliğina etkileri. Klinik Psikiyatri 23: 123-124.

32. DePierro J, Lowe S, Katz C (2020) Lessons Learned from 9/11: Mental health perspectives on the COVID-19 pandemic. Psychiatry Res 288: 113024.

33. McAlonan GM, Lee AM, Cheung V, Cheung C, Tsang KWT, et al. (2007) Immediate and sustained psychological impact of an emerging infectious disease outbreak on health care workers. Can J Psychiatry 52: 241-247.

34. Xiao H, Zhang Y, Kong D, Li S, Yang N (2020) The effects of social support on sleep quality of medical staff treating patients with Coronavirus Disease 2019 (COVID-19) in January and February 2020 in China. Med Sci Monit 26: e923549.

35. Ye L, Yang S, Liu C (2020) Infection prevention and control in nursing severe coronavirus disease (COVID -19) patients during the pandemic. Critical Care 24: 2-4.

36. Ozkol Kilinc K, Ozturk H (2019) Hemşirelikte Hizmetkâr Liderlik. IV. Uluslararasi Kültür Sempozyumlari: Uluslararsi Sağlik Toplum ve Kültür Sempozyumu. Sempozyum, KIBATEK, Amasya, 170-180.

37. Denat Y, Dikmen Y, Yilmaz G, Karalar D (2018) Hemşirelik Öğrencilerinin Tükenmişlik Düzeyi ve Etkileyen Etmenlerin İncelenmesi. Dokuz Eylül Üniversitesi Hemşirelik Fakültesi Elektronik Dergisi 11: 218-223.

38. Tekir Ö, Çevik C, Arik S, Ceylan G (2016) Sağlik çalişanlarinin tükenmişlik, iş doyumu düzeyleri ve yaşam doyumunun incelenmesi. Kirikkale Üniversitesi Tip Fakültesi Dergisi 18: 51-63. 